\title{
Synthesis and Structural Studies of Nanowires Composite Materials from Rice Husk Ash by Metallothermic Processes
}

\author{
Ladarat Kanlayavisut ${ }^{1}$, Pitchanunt Chaiyo ${ }^{1}$, Ki-Seok An ${ }^{2}$, Supon Sumran ${ }^{1}$, Supakorn Pukird ${ }^{1, *}$ \\ ${ }^{1}$ Department of Physics, Faculty of Science, Ubon Ratchathani University, Thailand \\ ${ }^{2}$ Thin Film Materials Laboratory, Korea Research Institute of Chemical Technology, South Korea
}

Copyright $\subseteq 2016$ by authors, all rights reserved. Authors agree that this article remains permanently open access under the terms of the Creative Commons Attribution License 4.0 International License

\begin{abstract}
Nanowires composite materials were synthesized from rice husk ash using by two metallothermic processes. The rice husk ash and carbon charcoal were mixed with $\mathrm{Mg}$ and $\mathrm{Sn}$ metals by various ratios and heated at $700^{\circ} \mathrm{C}$ and $1000^{\circ} \mathrm{C}$ under atmosphere of nitrogen gas. The formed products were studied by scanning electron microscope (SEM) and X-rays diffraction (XRD) technique. SEM images showed the structures of nanowires composite materials with diameter around 50-300 nm and length of more a few $10 \mu \mathrm{m}$. XRD patterns indicated the crystal structures of composite materials consisting of $\mathrm{Si}, \mathrm{MgO}$, $\mathrm{Mg}_{2} \mathrm{SiO}_{4}$ phase and $\mathrm{SiC}, \mathrm{SnO}_{2}$ phase.
\end{abstract}

Keywords Nanowires Composite Materials, Rice Husk Ash, Metallothermic Processes

\section{Introduction}

Rice husks are very abundant waste products soluble in the rice farm. The components of rice hush contained of $13-29 \%$ inorganic materials and $87-97 \%$ of $\mathrm{SiO}_{2}$ (silica) in an amorphous state [1-4]. Some impurities are metal oxides of $\mathrm{Na}, \mathrm{K}, \mathrm{Mg}, \mathrm{Ca}$ and $\mathrm{Fe}$ etc., and silicates can vary from 3 to $13 \%$ in ash. These metal oxides can be taken out by acid-leaching. The rice husk ash was used to produce useful materials such as silica, silicon carbide, and silicon nitride [1-9]. Silica is a group IV metal oxide with the properties of good abrasion resistance, electrical insulator and high thermal stability. It is not soluble in all acids except for hydrogen fluoride (HF). Silica from rice husk ash is used as ceramic materials both a precursor of other ceramic products and silicon materials. The amorphous silica is a basic source of pure silicon, which is used in manufacturing photovoltaic or solar cells for electric generation [1-8]. The producing of silicon in rice husk can be prepared from two processes, the carbothermic reduction reaction, $2 \mathrm{C}+\mathrm{SiO}_{2}=\mathrm{Si}+2 \mathrm{CO}$, and metallothermic reduction such as, $2 \mathrm{Mg}+\mathrm{SiO}_{2}=\mathrm{Si}+2 \mathrm{MgO}$, or $2 \mathrm{Ca}+\mathrm{SiO}_{2}=\mathrm{Si}+2 \mathrm{CaO}[1-4,7-8]$. Many previous papers showed that $\mathrm{SiO}_{2}$ and metal oxides could be synthesis to forming nanostructure materials such as nanowires, nanorods, nanobelts and nanoparticles by various methods [10-15].However, $\mathrm{MgO} / \mathrm{SnO} 2$ core-shell heteronanowires, metal-shelled coaxial nanowires $\mathrm{SnO} 2$-branched and ultrafine $\mathrm{SnO} 2$-carbon matrix composites have been also synthesized [16-18]. The starting rice husk source can be used for synthesized of nano-structured silica [19-20], $\mathrm{SiO}_{2}$ nanowires [21], porous silica [22], and silicon nanostructured for high performance Li-ion battery anodes [23]. In this paper, we would like to synthesis the nanowires composite materials from rice husk ash by using metallothermic processes.

\section{Experimental Procedure}

We have been synthesized nanowires composited materials by using metalothermic process. The rice husk ash powder are prepared by heating clean rice husk at $700^{\circ} \mathrm{C}$ under atmosphere of nitrogen gas around $1 \mathrm{hr}$. The rice husk ash, carbon charcoal and $\mathrm{Mg}$ ribbon were mixed with ratio of 2:0.1:1 by weight and put in alumina boat. The $\mathrm{SiO}_{2} / \mathrm{Si}$ substrates were put in alumina boat. The alumina boat and samples were taken place on the middle of furnace quartz tube. The furnace quartz tube was heated at $1000^{\circ} \mathrm{C}$ around $1 \mathrm{hr}$ under nitrogen gas with flow rate of $1.5 \mathrm{~L} / \mathrm{min}$. For comparison, we used rice husk ash and carbon charcoal mixed with $\mathrm{Sn}$ powder, ratio of 1:0.1:0.1 by weight heated at $700^{\circ} \mathrm{C}$ under atmosphere of nitrogen gas around $1 \mathrm{hr}$. When, the heating temperature was got up to setting point. The furnace tube was cooled down to room temperature, nationally. The heated powder and substrates were taken out from the furnace tube. We can observe the difference 
color from starting materials source both powder and substrates. SEM and XRD have been used for structural studies of these prepared products. The results showed in the follow figures.

\section{Results and Discussion}

After, the furnace was cooled down to room temperature. The heating powder and substrates were investigation by SEM and XRD. Fig. 1 showed SEM images of heating powder from the first process, the heated mixing of rice husk ash, carbon charcoal and $\mathrm{Mg}$ ribbon.
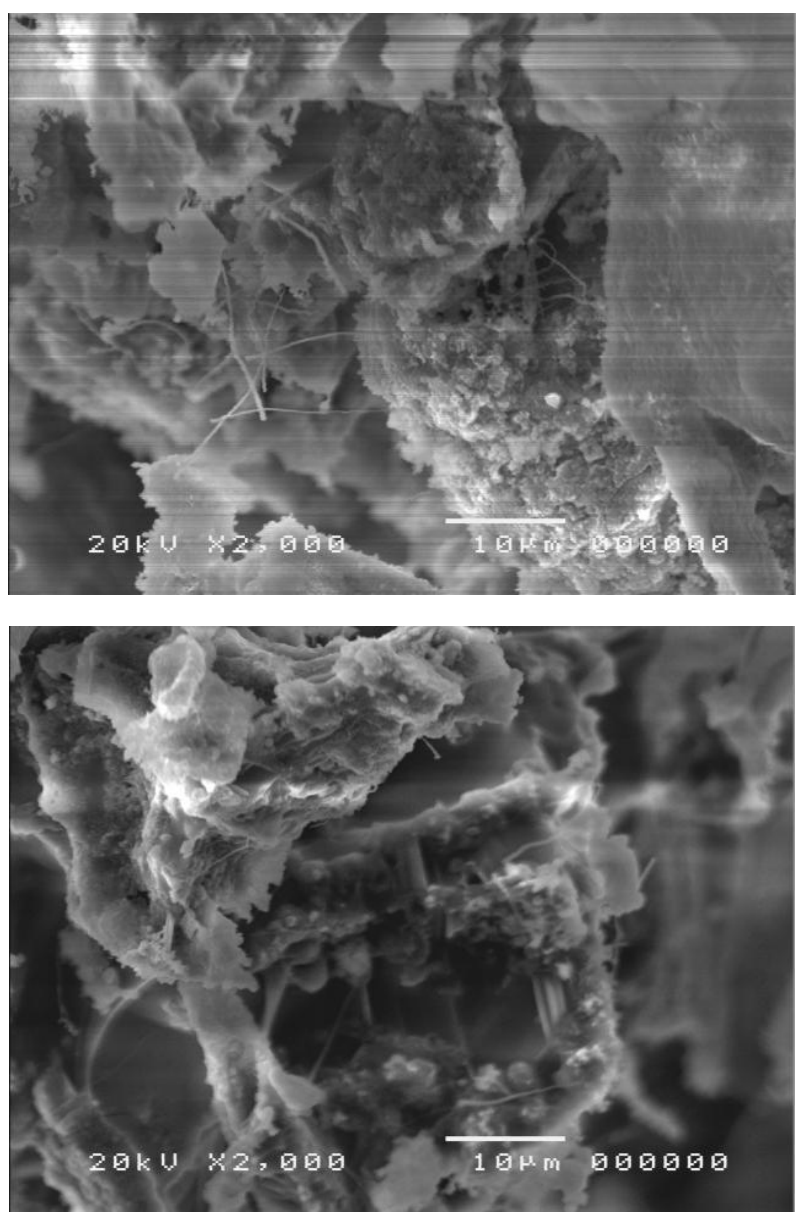

Figure 1. SEM images of heating powder from the first process

We can observe some nanowires-like materials growth up from mixing powder with diameter around $100 \mathrm{~nm}$ and length of a few micrometers. The XRD technique have been used for studying the consisting of nanowires composite materials and powder.

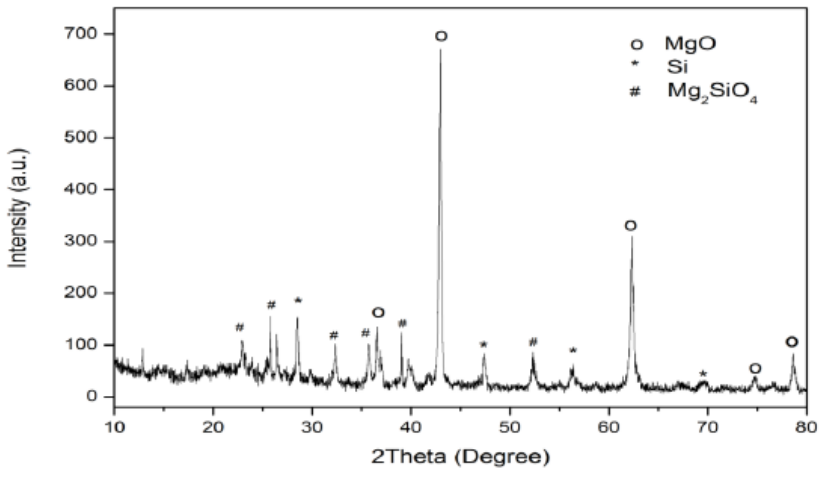

Figure 2. XRD patterns of heating powder from the first process

Fig. 2, the XRD patterns show the compound of the mixing nanowires composite materials have phase structures of $\mathrm{MgO}, \mathrm{Si}$ and $\mathrm{Mg}_{2} \mathrm{SiO}_{4}$. These materials may be used for thermoelectric materials and comparison with normal structures of them. The general metallothermic process can be showed follow by, $3 \mathrm{SiO}_{2}+4 \mathrm{Mg}=2 \mathrm{Si}$ $+2 \mathrm{MgO}+\mathrm{Mg}_{2} \mathrm{SiO}_{4}$. The equation revealed the reduction of $\mathrm{Mg}$ from $\mathrm{SiO}_{2}$ by using matallothermic process for producing $\mathrm{Si}$. We can easily move $\mathrm{MgO}$ and $\mathrm{Mg}_{2} \mathrm{SiO}_{4}$ by acid and heat treatment for getting $\mathrm{Si}$ nanostructure materials, no appear in this paper.
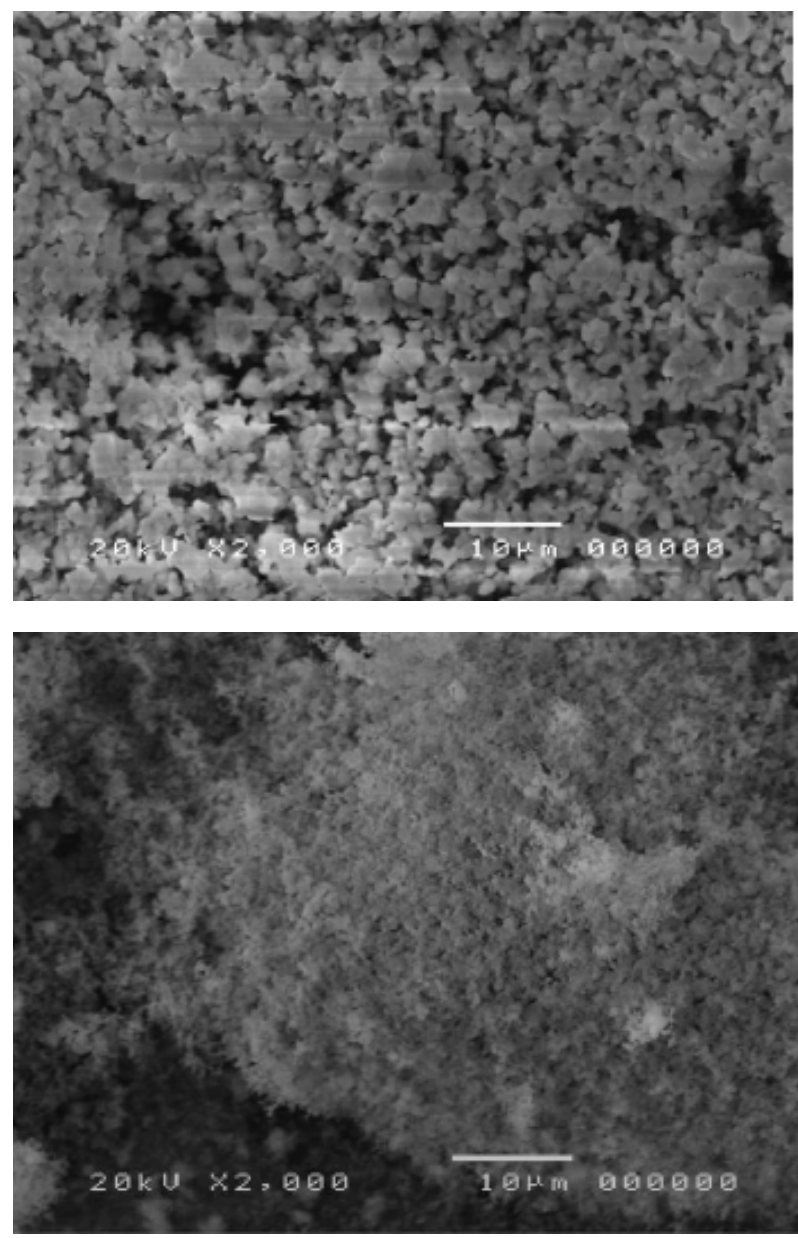

Figure 3. SEM images of the synthesized products on substrate from the first process 
Fig. 3 showed SEM images of synthesized product on substrate from first metallothermic process. The white gray color can be observed on substrate by naked eyes. SEM images showed some clusters of particles and wires-like structures. The XRD patterns in Fig. 4 revealed that synthesized products consisting of $\mathrm{MgO}$ and Si phases.

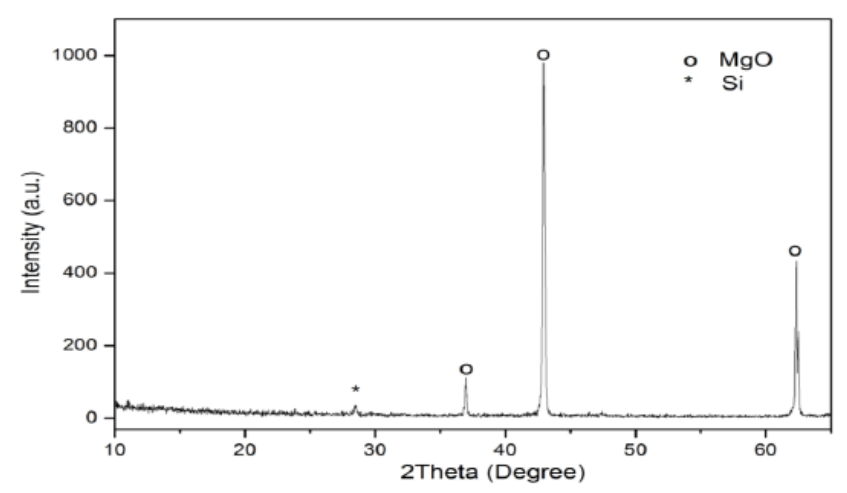

Figure 4. XRD patterns of synthesized products on substrate from first process

For comparison, we made the second metallothermic process by mixing rice husk ash, carbon charcoal and $\mathrm{Sn}$ metal powder. The heating powder and synthesized products on substrate can be studied in next pictures by SEM and XRD. Fig. 5 showed SEM images of heated mixing powder from second metallothermic process. We can observe the long nanowires-like and some particles. The diameter of nanowires are around 100-300 nm and length of more a few $10 \mu \mathrm{m}$. Fig. 6 , XRD patterns revealed the nanowires composite materials consisting of $\mathrm{SiC}, \mathrm{SiO}_{2}$ and $\mathrm{SnO}_{2}$ phase structures. The metallothermic process can be discussed follow by, $2 \mathrm{SiO}_{2}+\mathrm{C}+\mathrm{Sn}=\mathrm{SiC}+\mathrm{SiO}_{2}$ $+\mathrm{SnO}_{2}$.

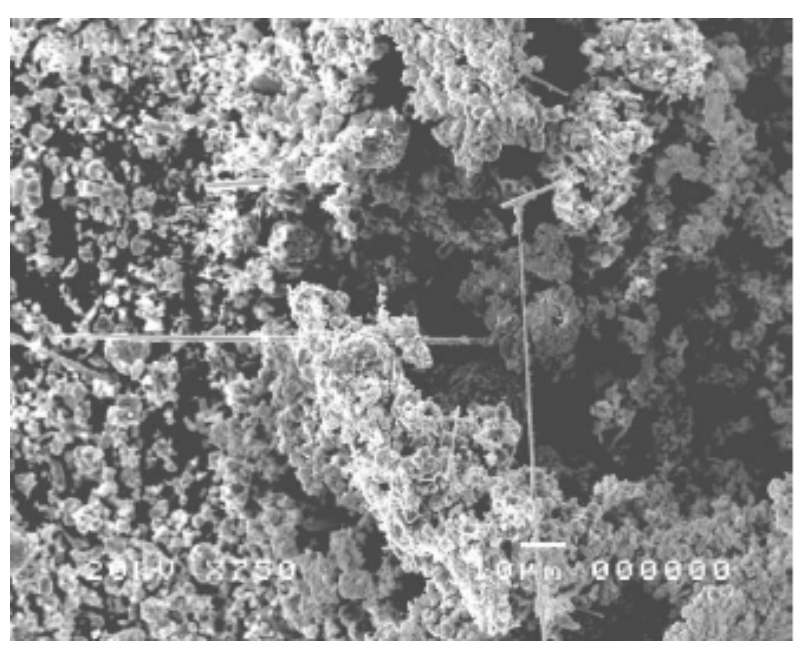

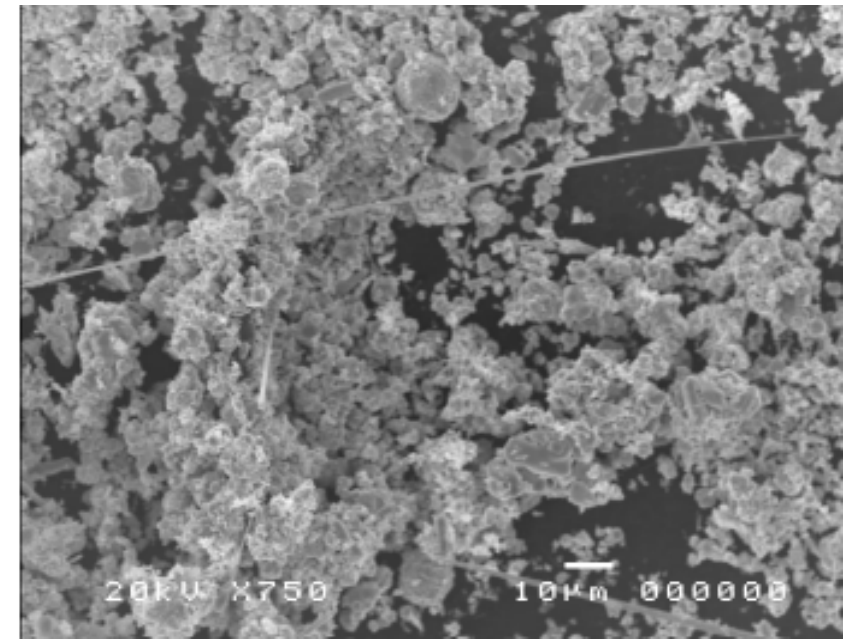

Figure 5. SEM images of heating powder from second metallothermic process

This metallothermic process may be not completed reduction due to still $\mathrm{SiO}_{2}$. However, $\mathrm{SiO}_{2}$ can be moved by HF treatment.

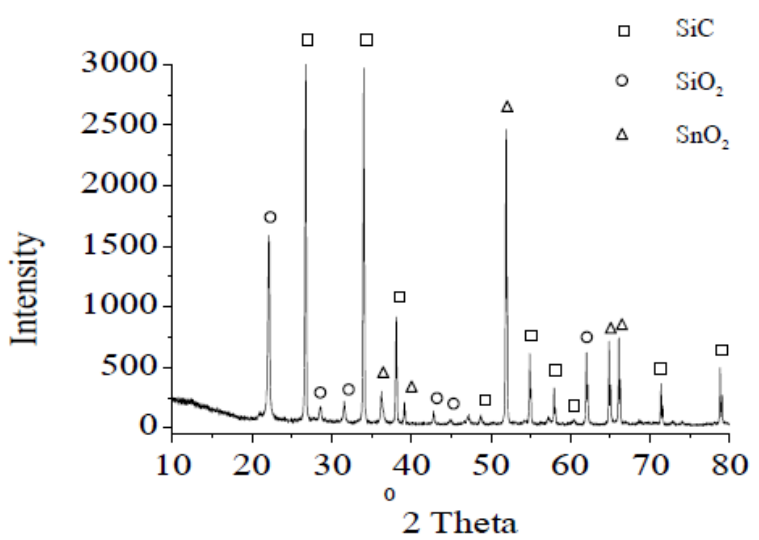

Figure 6. XRD patterns of heating powder from second metallothermic process

The morphologies of prepared products on substrate have been studied by SEM. Fig. 7, SEM images showed nanowires-like, nanorods-like and some cubic of particles composite materials. The XRD patterns revealed that these nanostructure composite materials consisting of $\mathrm{SiC}$ and $\mathrm{SnO}_{2}$ phases, shown in Fig. 8 . 

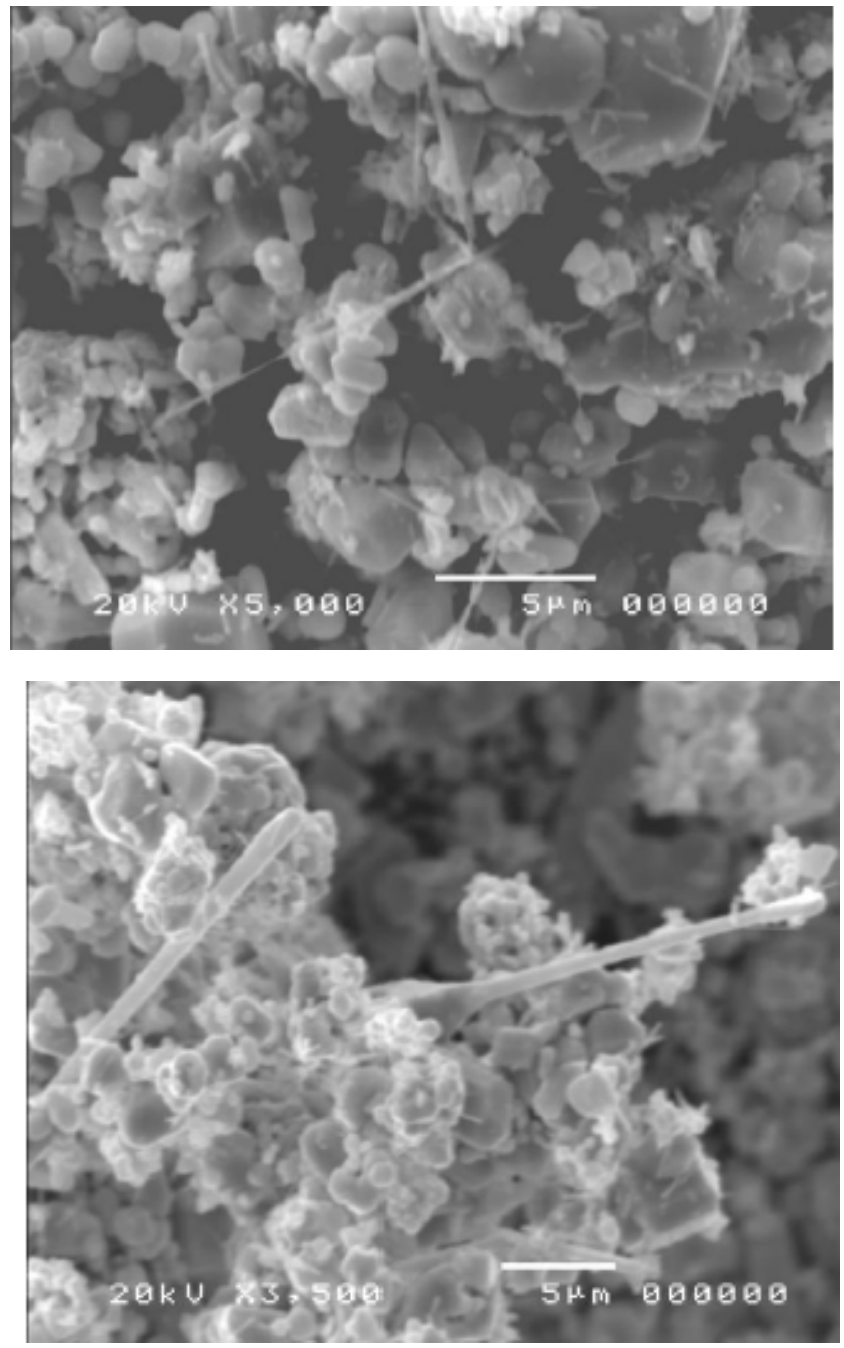

Figure 7. SEM images of synthesized products on substrate from second metallothermic process

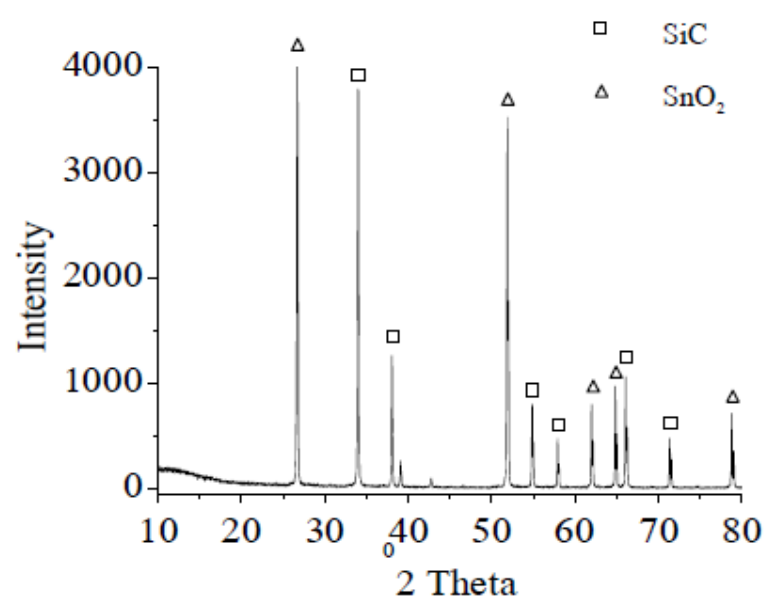

Figure 8. XRD patterns of synthesized products on substrate from second metallothermic process

Since, the limited of the instruments we have not clearly specific what kind of nanowires, $\mathrm{SiC}$ or $\mathrm{SiO}_{2}$ structures. The energy dispersive X-ray spectroscopy (EDS) can verify the elements consisting of nanowires phases. The XRD technique can only reveal the mixing phases of synthesis compound materials.

\section{Conclusions}

We have been synthesized nanowires composite materials from rice husk ash, as starting materials source. Nanowires composite materials were synthesized from rice husk ash using by two metallothermic processes. The synthesized products were studied by scanning electron microscope (SEM) and X-rays diffraction (XRD) technique. SEM images showed the structures of nanowires composite materials with diameter around 50-300 $\mathrm{nm}$ and length of more a few $10 \mu \mathrm{m}$. XRD patterns indicated the crystal structures of composite materials consisting of $\mathrm{Si}, \mathrm{MgO}$, $\mathrm{Mg}_{2} \mathrm{SiO}_{4}$ phase and $\mathrm{SiC}, \mathrm{SnO}_{2}$ phase.

\section{Acknowledgements}

This work is supported by Ubon Ratchathani University, Thailand and Korea Research Institute of Chemical Technology, Korea. The authors would like to thank them.

\section{REFERENCES}

[1] J. A. Amick, (1982) Purification of rice hulls as a source of solar grade silicon for solar cell, J. Electrochem. Soc. 29, (4), pp. 864-866.

[2] D. N. Bose, P.A. Govindacharyulu, H.D. Banerjee, (1982), Large grain polycrystalline silicon from rice husk. Sol. Energy Mater. 7, pp.319- 321.

[3] L.P. Hunt, J.P. Dismukes, J.A. Amick, (1984), Rice hulls as a raw materials for producing silicon, J. Electrochem. Soc. 131(7), pp.1683-1686

[4] P. Mishra, A. Chakraverty , H.D. Banerjee, (1985), Production and purification of silicon by calcium reduction of rice-husk white ash, J. Mater.Sci(20), pp.4387-4391.

[5] M. Patel, A. Karera, P. Prasanna, (1987), Effect of thermal and chemical treatment on carbon and silica contents in rice husk, J. Mater. Sci. (22), pp.2457-2464.

[6] Chakraverty, P. Mishra , H.D. Banerjee, (1988), Investigation of combustion of raw and acid- leach rice husk for production of pure amorphous white silica, J. Matler. Sci. (23), pp.21-24.

[7] N. Ikram and M. Akhter, (1988), X-ray diffraction analysis of silicon prepare from rice husk ash, J. Mater. Sci. (23), pp.2379-2381.

[8] K.C. Nandi, D. Mukherjee, A.K. Biswas and H.N. Acharya, (1991), Characterization of hydrogenated amorphous silicon films obtained from rice husk. Solid State Commun., 79,pp. 687-691. 
[9] Real, M.D. Aleala, J.M. Criado, (1996), Preparation of silica from rice husk, J. Am. Ceram. Soc. 79 (8), pp.2012-2016.RAM, M. AKHTERNAZMA IKRAM, M. AKHTER

[10] Z. Zhang, X.H. Fan, L. Xu, C.S. Lee and S.T. Lee, (2001), Morphology and growth mechanism study of self-assembled silicon nanowires synthesized by thermal evaporation, Chem. Phys. Lett., 337, pp 18-24.

[11] D.A. Dikin, X. Chen, W. Ding, G. Wagner and R.S. Ruoff, (2003), Resonance vibration of amorphous $\mathrm{SiO}_{2}$ nanowires driven by mechanical or electrical field excitation, J. Appl. Phys., 93(1), pp.226-230.

[12] X.Y. Kong, Y. Ding and Z. L. Wang, (2004), Metal-semiconductor $\mathrm{Zn}-\mathrm{ZnO}$ core-shell nanobelts and nanotubes, J. Phys. Chem. B108, pp.570-574.

[13] M. Asharf Shah and M.S. Al-Ghamdi, (2011), Preparation of copper $(\mathrm{Cu})$ and copper oxide $(\mathrm{Cu} 2 \mathrm{O})$ nanoparticles under supercritical conditions, Mater. Sci. Appl. 2(8) pp.977-980.

[14] G-J. Sun, S-W. Choi, S-H. Jung, A. Katoch and S.S. Kim, (2013), V-groove $\mathrm{SnO}_{2}$ nanowire sensors: fabrication and Pt-nanoparticle decoration, Nanotechnology 24 pp.025504-025512.

[15] K.P. Kalyanikutty, F.L. Deepak, Christopher Edem, A. Govindaraj, C.N.R. Rao,(2005), Carbon-assisted synthesis of nanowires and related nanostructures of $\mathrm{MgO}$, Mater. Res. Bull. 40, pp.831-839.

[16] H.S. Kim and H.W. Kim, (2009), Fabrication and Raman Studies of $\mathrm{MgO} / \mathrm{SnO} 2$ Core-Shell Heteronanowires, ACTA
Phys. Pol. A, 116(1), pp.58-61.

[17] H.S. Kim, S.E. Park, H.W. Kim, J.Y. Park, N. Jiang and S.S. Kim, (2010), Fabrication of metal- shelled coaxial nanowires and annealing-induced formation of metal nanoparticles for catalytic applications: Growth and characteristics of $\mathrm{SnO} 2$-branched nanostructures, Solid State Sci. 12, pp. 970-977.

[18] M. Gao, X. Chen, H. Pan, L. Xiang, F. Wu and Y. Liu, (2010), Ultrafine $\mathrm{SnO} 2$ dispersed carbon matrix composites derived by a sol-gel method as anode materials for lithium ion batteries, Electrochim. Acta 55, pp.9067-9074.

[19] R. Conradt, P. Pimkhaokham and U. Leela-Adison, (1992), Nano-structured silica from rice husk, J. Non-Cyrstl. Sol.,145, pp.75-79

[20] T-H. Liou, (2004), Preparation and characterization of nano-structured silica from rice husk, Mater. Sci. Eng. A364, pp. 313-323.

[21] S. Pukird, P. Chamninok, S. Sumran, P. Kasian, K. Noipa and L. Chow, (2009), Synthesis and characterization of $\mathrm{SiO}_{2}$ nanowires prepared from rice husk ash, J. Mat. Mater. and Miner, 19(2), pp. 33-37.

[22] Y. Shen, P. Zhao and Q. Shao, (2014), Porous silica and carbon derived materials from rice husk pyrolysis char, Micropor. Mesopor. Mat. 188, pp. 46-76.

[23] N. Liu, K.F. Huo, M.T. McDowell, J. Zhao and Y. Cui, (2013), Rice husks as a sustainable source of nanostructured silicon for high performance Li-ion battery anodes. Sci. Rep. 3(1919) pp.1-7. 